\title{
Investigating pull-out characteristics of tubular fabrics with different tightnesses in drilling and sampling process
}

\section{REZUMAT - ABSTRACT}

\section{Investigarea caracteristicilor de tracțiune ale țesăturilor tubulare cu diferite grade de compactitate}

în procesul de perforare și eșantionare

În acest studiu, caracteristicile de tracțiune ale țesăturilor tubulare cu patru grade diferite de compactitate au fost investigate prin intermediul sistemului de testare prin tracțiune automată. Între timp, principiul fenomenului lipire-alunecare în timpul procesului de perforare și de eșantionare a fost clarificat. Rezultatele experimentale obținute de la acest sistem au indicat că forța de tracțiune a țesăturilor tubulare a prezentat tendința de creștere în stadiul inițial, după care de scădere și, în cele din urmă, a avut tendința spre o valoare constantă non-zero. De asemenea, s-a demonstrat că, cu cât este mai mare compactitatea țesăturilor tubulare, cu atât este mai mare forța de susținere. În plus, conceptul de coeficient de netezire a fost introdus pentru a înțelege mai bine gradul de dificultate al țesăturilor tubulare care sunt extrase din conducta rotundă. Calculele au arătat că o compactitate mai mică a conferit o performanță mai bună la netezire și, în mod natural, coeficientul de netezire a fost mai mare.

Cuvinte-cheie: forța de tracțiune, coeficient de netezire, țesături tubulare, grade diferite de compactitate, fenomen de lipire-alunecare, perforare și eșantionare

\section{Investigating pull-out characteristics of tubular fabrics with different tightnesses in drilling and sampling process}

In this paper, the pull-out characteristics of tubular fabrics with four different tightnesses were investigated via our self-designed pull-out testing system. Meanwhile, the principle of stick-slip phenomenon during the drilling and sampling process was clarified. Experimental results obtained from this system indicated that pull-out force of tubular fabrics presented a tendency of rising in the initial stage then decreasing, and finally tended towards a constant non-zero value. It also revealed that the bigger the tightnesses of tubular fabrics are, the larger its bearable force is. Moreover, the concept of smoothness coefficient was introduced to further understand the degree of difficulty that tubular fabrics pulled out from round pipe. The calculations showed that smaller tightnesses gave better smoothness performance, and naturally the smoothness coefficient was bigger.

Keywords: pull-out force; smoothness coefficient; tubular fabrics; different tightnesses; stick-slip phenomenon; drilling and sampling

\section{INTRODUCTION}

In recent years, with the outstanding properties of non-laddering and seamless comparable to conventional fabrics, there has been an increasing interest in tubular fabrics for practical applications in the fields of medical materials, pipeline rehabilitation [1-5], etc. Besides, tubular fabrics used as thin strip sampling apparatuses and sample collection bags to implement stratigraphic drilling and to collect samples of soils and small solids have also attracted much attention in the fields of space technology, geological assay and archaeological discovery [6-7].

Because the interaction relationship between tubular fabrics and round pipe in actual use is very complex, research on the force of tubular fabrics pulled out from round pipe in drilling process is needful and the development of corresponding equipment or device is also indispensable. Moreover, there are many factors that are impacting on the pull-out process of tubular fabrics along the wall of round pipe. For the purpose of better analyzing movement condition of tubular fabrics along the wall of round pipe, Zhao
Chao revised Euler's formula. In addition, a test device for measuring pull-out force of tubular fabrics was designed based on Instron instrument, it was found that the coated length of tubular fabrics and positive pressure to round pipe had positive correlation with pull-out force [8]. Qian Xiuyang and colleagues measured the friction coefficient between tubular fabrics and the wall of round pipe applying elastic element and elastic pressure method [9]. Through establishing mechanical model of drilling process, Luo Shihua explored the relationship between the stress of tubular fabrics at the end of round pipe and the length that coated. As well, dynamic numerical simulation was conducted to investigate pull-out process of tubular fabrics based on anisotropic constitutive model of materials, they also discovered that wall thickness and inner diameter of round pipe and the thickness of tubular fabrics all influenced pull-out process, in turn, made it unfavorable for tubular fabric to pull out from round pipe [10]. However, a specialized system for testing pullout force of tubular fabrics during drilling and sampling hasn't been developed and the principle of 
volatility in this process does not reflect reasonably and most of these evaluation standards concentrated on the physical properties of tubular fabric or round pipe, characterization techniques and analysis method aimed at the structure of tubular fabrics were less reported.

Pull-out process of tubular fabrics is a nonlinear deformation process, which has very complex influence factors. If there are failure conditions of selflocked or blocked, it will make the drilling and sampling process difficult to carry out. Hence, investigating pull-out characteristics of tubular fabrics in drilling and sampling process is significant. This paper deals with the fabrication of four different tightnesses tubular fabrics and design of pull-out system so as to investigate pull-out force of tubular fabrics along the wall of round pipe, and then to explore smoothness coefficient.

\section{EXPERIMENTAL DETAILS}

\section{Nomenclature}

The parameters used in the derivation process are listed in table 1.

\section{Manufacturing of tubular fabrics}

Herein, the basic parameters of materials used to fabricate tubular fabrics are shown in table 2. The diameters $d$ of the four tubular fabrics are identically equal to $24 \mathrm{~mm}$.

The parameters of the four tubular fabrics with different tightnesses and the corresponding calculative formulas [11] are shown in table 3.
As shown in figure $1, a$ and $1, d$, when weaving begins, according to the weave design in figure 1, $c$, under the action of pneumatic pressure, picking rod is drawn out with the special shuttle in figure $1, b$ connected from picking mouth, passes through shed into the opposite card slot, then picking rod comes back into picking mouth left behind the shuttle in card slot, and the first weft insertion is completed. When next shed is formed, picking rod is thrown out from picking mouth, and passes across shed towards card slot, where shuttle is released and clamped with oncoming picking rod, then picking rod carries shuttle back again into picking mouth, and the second weft insertion is accomplished. Picking rod and shuttle repeat this process again and again thereby weft yarns are inserted and tubular fabrics are manufactured [12].

\section{Self-designed pull-out testing system of tubular fabrics}

As shown in figure 2, a pull-out system for measuring pull-out force of tubular fabrics is self-designed. The system mainly consists of two modules, one is drilling and sampling mechanism in figure $2, b$ and the other is a signal receiving system [13].

Before the movement of drilling and sampling mechanism, hollow bit is in contact with soil particles but not drills, one end of tubular fabric is sheathed on the outer wall of round pipe, the other end is inverted into the corner and clamped by a rope. Round pipe is placed into hollow auger drill pipe. During drilling and sampling, lifting plate moves downward along the four guide rails with the traction of adjusting speed

Table 1

\begin{tabular}{|c|c|c|c|}
\hline Symbols & Meaning & Symbols & Meaning \\
\hline$N_{D}$ & Fineness of Kevlar filament & $Z$ & Cycle numbers of basic weave \\
\hline$\delta_{y}$ & Density of Kevlar filament & $S_{w}$ & Progression of weft direction \\
\hline$d_{y}$ & Diameter of Kevlar filament & $E_{z}$ & Total tightness \\
\hline$M_{j}$ & Total warp ends & $E_{j}$ & Warp tightness \\
\hline$P_{j}$ & Warp density of a single layer & $E_{w}$ & Weft tightness \\
\hline$R_{j}$ & Ends of basic weave cycle & $P_{w}$ & Weft density of a single layer \\
\hline
\end{tabular}

\begin{tabular}{|c|c|c|c|c|}
\hline Materials & $\boldsymbol{N}_{\boldsymbol{D}}(\mathbf{D})$ & $\delta_{\boldsymbol{y}}\left(\mathbf{g} / \mathbf{c m}^{3}\right)$ & $\boldsymbol{d}_{\boldsymbol{y}}(\mathbf{m m})$ & \multirow{2}{*}{$d_{y}=0.01189 \sqrt{\frac{N_{D}}{\delta_{y}}}$} \\
\hline Kevlar filament & 800 & 1.44 & 0.28 & \\
\hline
\end{tabular}

THE PARAMETERS OF TUBULAR FABRICS

\begin{tabular}{|c|c|c|c|c|}
\hline Tubular fabrics & $M_{j}$ (roots) & $P_{j}($ roots $/ 10 \mathrm{~cm})$ & $E_{z}(\%)$ & $M_{j}=\pi d \cdot P_{j}, \quad M_{j}=R_{j} \cdot Z+S_{w}$ \\
\hline $1 \#$ & 167 & 220 & 85.3 & $E_{j} \cdot E_{w}$ \\
\hline $2 \#$ & 151 & 200 & 80.6 & $\overline{100}$ \\
\hline $3 \#$ & 137 & 180 & 75.4 & $=d_{y} \cdot P_{i}+d_{y} \cdot P_{w}-\frac{d_{y} \cdot P_{j} \cdot d_{y} \cdot P_{w}}{}$ \\
\hline $4 \#$ & 121 & 160 & 69.5 & 100 \\
\hline
\end{tabular}




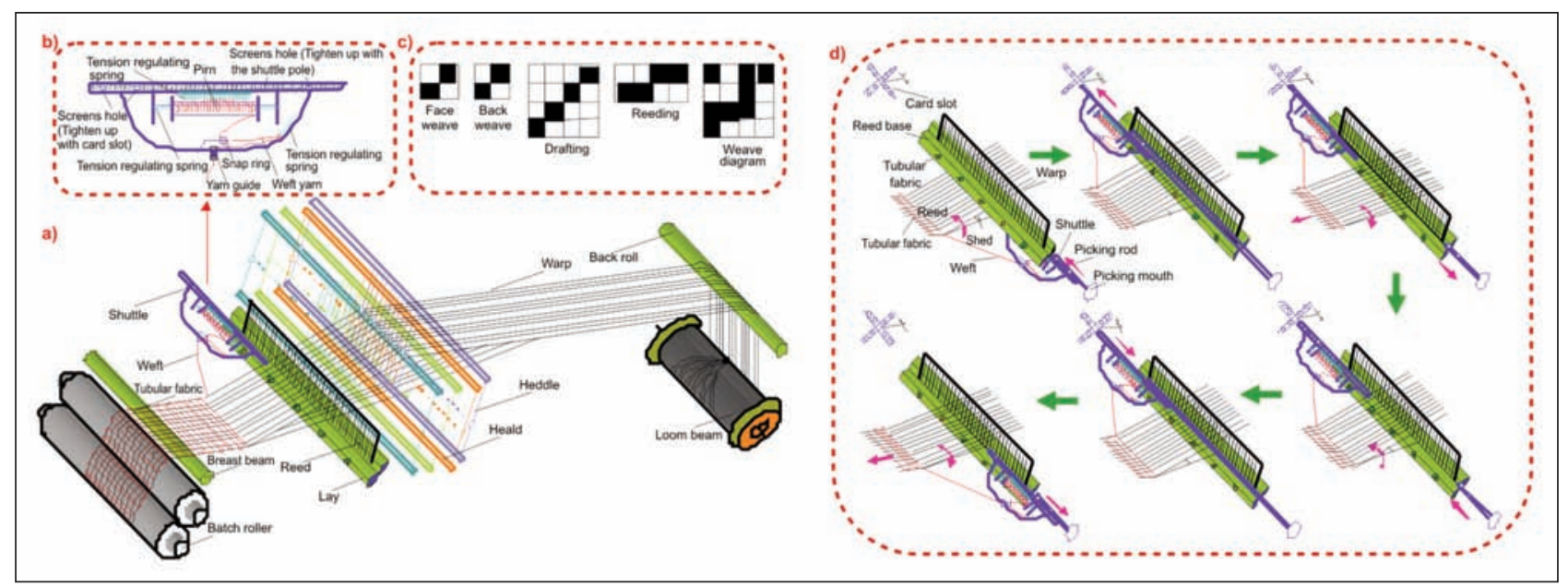

Fig. 1. (a) Weaving process of tubular fabric; (b) special shuttle; (c) diagram of weave design; (d) process of picking

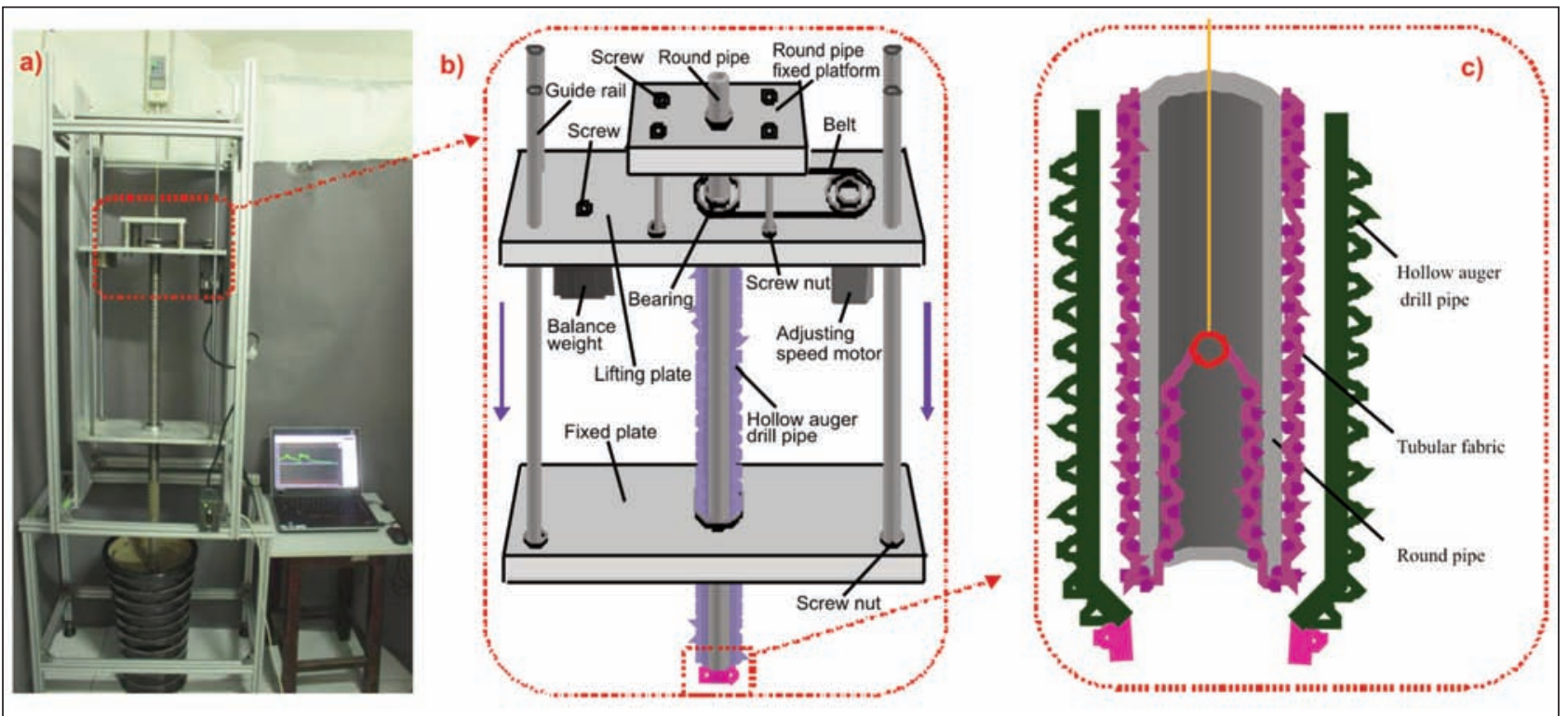

Fig. 2. (a) Self-designed pull-out system of tubular fabrics; (b) Drilling and sampling mechanism; (c) Location relationship of tubular fabric, round pipe and hollow auger drill pipe

motor, and drives hollow auger drill pipe to make spiral movement downward together, but round pipe only does vertical motion under the action of fixed platform. Along with tubular fabric completely entered into the inner of round pipe, soil particles are coated, as demonstrated in figure 3.

\section{RESULTS AND DISCUSSION}

\section{The principle of stick-slip phenomenon}

During drilling, the upper end of rope is fixed, round pipe moves downward uniformly with speed v0. For ease of analysis, it is assumed that round pipe is stationary and rope does upward movement relative to round pipe at a speed of $\mathrm{v} 0$, as shown in figure $4, a$. As shown in figure $4, b$, after drilling, rope is gradually tightened, force $F$ increases but not yet in excess of maximum static friction force $f_{\text {max }}$, hence tubular fabric is still in static state. As drilling proceeds, $F$ progressively increases till to exceed $f_{\max }$ at point $A$, when tubular fabric begins to move and is gradually flattened out from folded state and friction force $f$ therewith decreases. Then, tubular fabric does accelerated movement that acceleration a increases gradually and speed $v$ aggrandizes accordingly. At point $B, v$ is equal to $v_{0}$, thus, rope is tightened, $F$ and $a$ reached maximum value. However, with disappear of folded state at point $C, f$ is minimum and equal to $F$. For the fact that $v$ is still greater than $v_{0}$, hence $F$ gradually reduces. However, $f$ becomes bigger with the increase in length of tubular fabric inserted into the inner of round pipe. Thus, $v$ begins to reduce, till to point $D$. Considering that $F$ is less than $f, v$ continuously reduces till to zero, when tubular fabric stops moving and $f$ turns into static friction force. Then, as round pipe continues downward, it comes into next cycle movement [14-15]. 


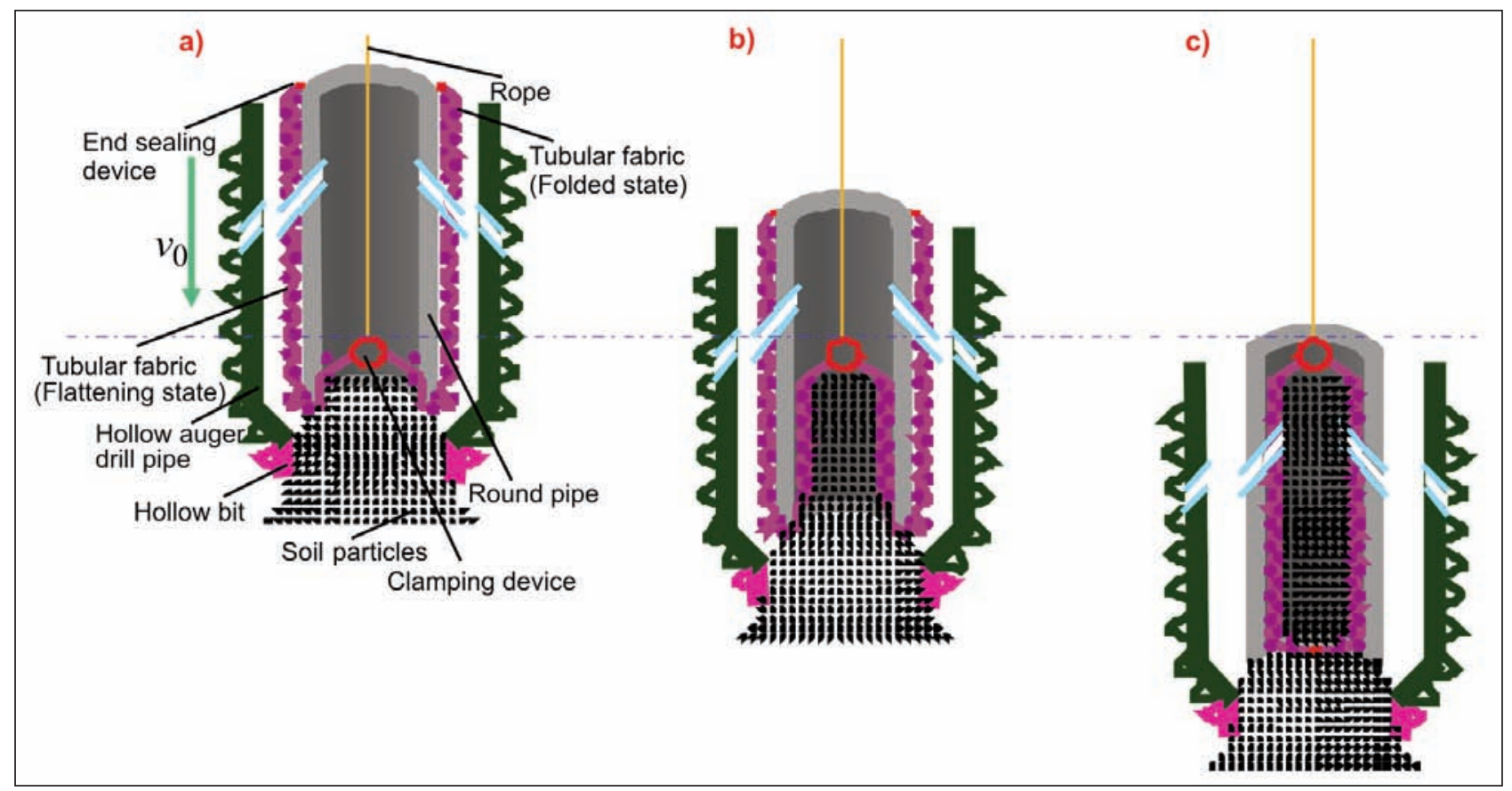

Fig. 3. The principle and process of drilling and sampling: (a) folded state exists; (b) folded state completely vanishes; (c) the end of drilling and sampling process

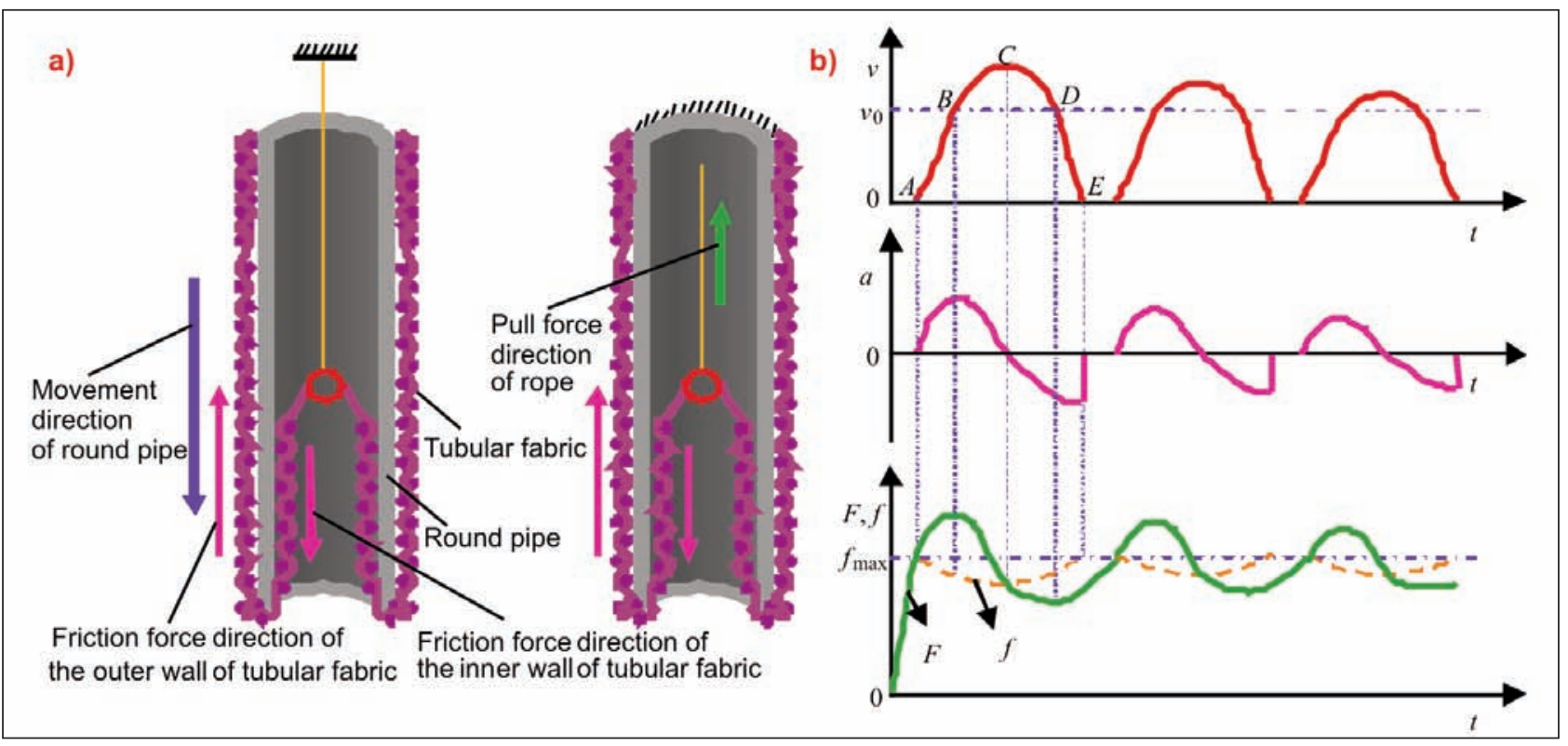

Fig. 4. (a) Equivalent diagrams of the motion of round pipe and rope; (b) the principle of stick-slip phenomenon

\section{The concept of smoothness coefficient}

In order to further explore and analyze the interaction force between tubular fabric and the wall of round pipe, a concept of smoothness coefficient is introduced and the formula is [12]:

$$
S=1-\frac{F_{\text {max }}}{F_{b}}
$$

Where, $S$ is smoothness coefficient of tubular fabrics, $F_{\text {max }}$ - maximum pull-out force obtained from the experiment, $F_{b}$ - breaking strength of tubular fabrics obtained from Instron instrument.
Smoothness coefficient is the degree of difficulty that tubular fabrics pulled out from round pipe and the values range from 0 to 1 . The greater the value, the smaller the effect of tubular fabric on the wall of round pipe, that is to say, the characteristic of smoothness is better.

\section{Pull-out force-time and smoothness coefficient-time curves}

As can be seen from figure $5, a$, the tendency of the four curves is approximately coincident and every curve demonstrates a tendency that first rises and then falls. During drilling and sampling, because the existence of stick-slip phenomenon, it can be clearly 

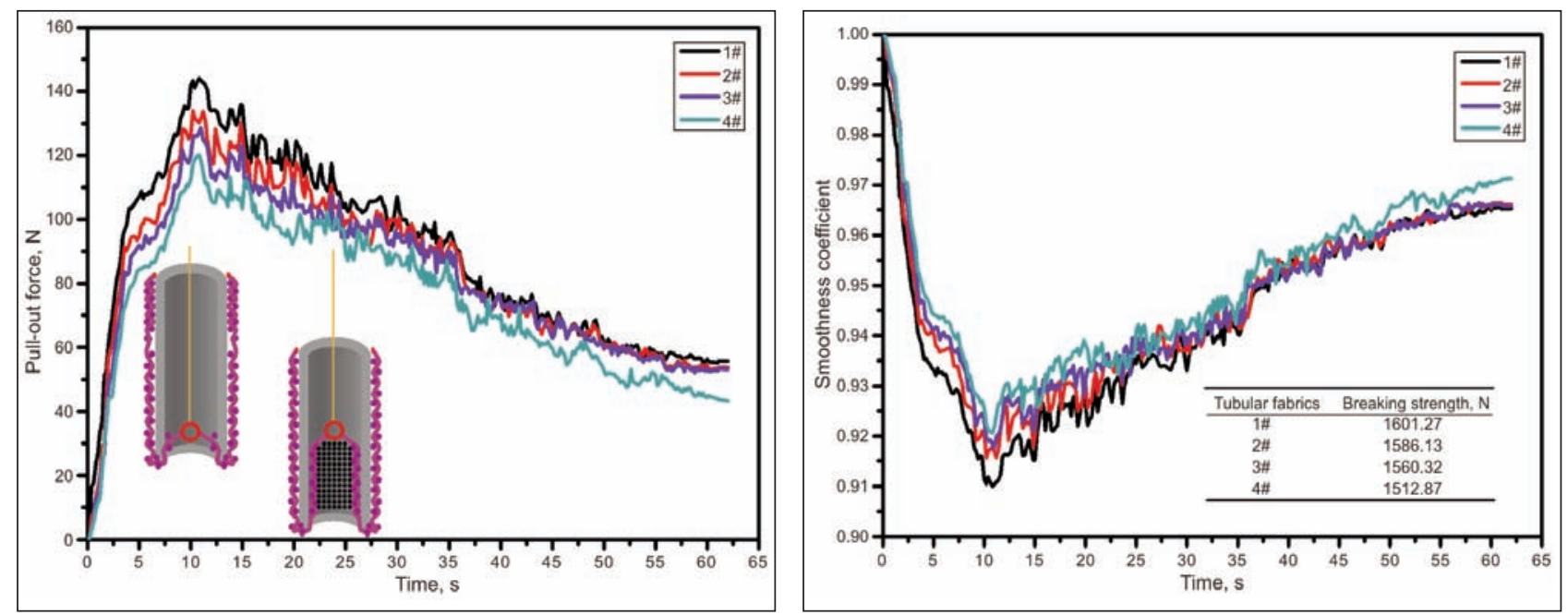

Fig. 5. (a) Pull-out force-time curves; (b) Smoothness coefficient-time curves

seen that pull-out force-time curves are highly volatile in the whole process. Moreover, it can also be seen that forces increase quickly compared to time from zero to a maximum value, after which point, forces decrease and finally move toward a constant value that is greater than zero. Actually, the process can be divided into two stages, folded state exists (about $0 \sim 11 \mathrm{~s}$ ) and folded state vanishes ( about 11 62 s), so pull-out forces of tubular fabrics presented a tendency of rising in the initial stage then decreasing, and finally tended towards a constant non-zero value. Pull-out force reaches maximum value when tubular fabrics in folded state are completely dismissed.

It can also be found that high tightnesses exhibit higher pull-out forces compared to low ones, however, an opposite way to smoothness coefficients, as shown in figure $5, b$. The differences can be attributed to the construction of tubular fabric, in reality, the interaction force between tubular fabrics and round pipe is the squeezing and friction between filaments of tubular fabrics and the wall of round pipe, hence, the bigger the filaments contact with the wall, the more intense the interaction[16-18]. High tightnesses have a big contact area, which leads to large pull-out force consequently. There is also another phenomenon from figure $5, b$, smoothness coefficients all exceed 0.90 , which gives a signal that characteristics of smoothness is good for tubular fabric when pulled out from round pipe.

\section{CONCLUSIONS}

In conclusion, this paper manufactures a high-performance tubular fabric and designs a pull-out system, with which a pull-out test was conducted. Because of the existence of stick-slip phenomenon, when tubular fabrics pulled out from round pipe, pull-out forces are highly volatile. From folded state to completely flattening state, pull-out forces presented a tendency of rising in the initial stage then decreasing, and finally tended towards a constant non-zero value. The results also indicate that high tightnesses have higher pull-out forces compared to low ones, but an opposite way to smoothness coefficients.

\section{ACKNOWLEDGEMENTS}

This research was financially supported by the National Key R\&D Program of China (2016YFC0802802).

\section{BIBLIOGRAPHY}

[1] Liu Y.H., Zhang P.H. Characterization and modeling of compression behaviors of biodegradable polydioxanone biliary stent for human body, In: Industria Textila, 2016, vol. 67, no. 1, pp. 62-70.

[2] Li G., Li Y., Lan P., He X.W., Zhao Z., Li Z., Hu H. Study of heat-setting treatment for biomedical polydioxanone stents, In: Journal of industrial textiles, 2016, vol. 46, no. 1, pp. 75-87.

[3] Zhang Q., Zhuang X.M., Lei M., Yan X. The structure and performance study of woven tubular artificial ligament. In: Technical Textiles, 2016, vol. 34, no. 4, pp. 20-23.

[4] Hao Z.X., Zhang S.J., Wang R., Xiao Q. Structure design of enhanced body of tubular fabric composite material for pipeline rehabilitation, In: Technical Textiles, 2010, vol. 28, no. 6, pp. 11-16.

[5] Zhang S.J., Wang R., Wang H., Zhang L. Textile liner design of pipeline trenchless textile lining renovation, In: Technical Textiles, 2007, vol. 25, no. 2, pp. 10-13.

[6] Quan Q.Q., Shi X.M., Tang D.W., Jiang S.Y., Deng Z.Q. Analysis and test research on influencing factors of drilling and coring quantity of lunar soil stimulant. In: Journal of Beijing University of Aeronautics and Astronautics, 2015, vol. 41, no. 11, pp. 2052-2060. 
[7] Shi X.M., Deng Z.Q., Quan Q.Q., Tang D.W., Hou X.Y., Jiang S.Y. Development of a drilling and coring test-bed for lunar subsurface exploration and preliminary experiments, In: Chinese Journal of Mechanical Engineering, 2014, vol. 27, no. 4, pp. 673-682.

[8] Zhao C. Correlation analysis and experiment of reversal lining pulling process of soft sampling bag, In: Master's Thesis, Tianjin Polytechnic University, 2016.

[9] Qian X.Y., Wang H.X., Yin C., Meng W.J., Wen G.L. Measurement system of friction coefficient between the tubular woven fabric and the pipe. In: Chinese Journal of Scientific Instrument, 2016, vol. 37, no. 12, pp. 2880-2886.

[10] Luo S.H. Finite element dynamic simulation in reversal lining pulling process of soft sampling bag, In: Master's Thesis, Tianjin Polytechnic University, 2015.

[11] Yao M. Textile materials science, In: China Textile \& Apparel Press, 1990.

[12] Ding Z.W., Yu W.D. Formation and characterization of pull-out smoothness of Minor-Caliber Tubular Fabrics (MCTFS). In: Journal of Donghua University(Natural Science Edition), 2017, vol. 43, no. 5, pp. 25-31.

[13] Ding Z.W., Yu W.D. Force analysis of tubular fabric during drilling and sampling. In: Textile Research Journal, DOI: 10.1177/0040517517729384

[14] Kadir B. Stick-slip behavior of para-aramid (Twaron ${ }^{\circledR}$ ) fabric in yarn pull-out, In: Textile Research Journal, 2013 , vol. 83, no. 1, pp. 13-33.

[15] Qiao F. Analysis and experimental study of the lunar soil core component characteristics. In: Master's Thesis, Harbin Institute of Technology, 2013.

[16] Kadir B. Experimental determination of yarn pull-out properties of para-aramid (Kevlar $\left.{ }^{\circledR}\right)$ woven fabric, In: Journal of Industrial Textiles, 2011, vol. 41, no. 3, pp. 201-221.

[17] Kadir B. In-plane shear properties of para-aramid (Kevlar ${ }^{\circledR}$ ) fabric by yarn pull-out method, In: Journal of Industrial Textiles, 2011, vol. 42, no. 1, pp. 76-96.

[18] Kadir B., Mahmut K. Single and multiple yarn pull-outs on aramid woven fabric structures, In: Textile Research Journal, 2010, vol. 81, no. 8, pp. 847-864.

\section{Authors:}

\section{ZUOWEI DING}

WEIDONG YU

Donghua University, College of Textiles, Key Laboratory of Textile Science \& Technology, Ministry of Education, 2999 North Renmin Road, Songjiang District, 201620, Shanghai, P.R.China e-mail: dingzuowei2009@163.com,wdyu@dhu.edu.cn

Corresponding author:

ZUOWEI DING

e-mail: dingzuowei2009@163.com 